\title{
15 Niches where Latin survived longer
}

O quoties obitum linguae statuere Latinae!

Tot tamen exsequiis salva superstes erat.

'Oh how often have they declared the death of Latin! As many times it survived its funeral.'

Eberle (Sal niger, Sal 19)

\$1 In fact, Latin did not cease to be of scientific importance in all branches of science and learning in the early nineteenth century. Its displacement happened later in parts of Europe where none of the three major languages was at home, as well as in some fields, such as philology and linguistics, where it was still alive and well in the middle of the nineteenth century or later (\$1). Six niches where Latin continued to thrive into the twentieth century will be examined below $(\S \S 2-7)$.

We have seen that the vernaculars took over Latin's leading rôle as language of science and learning around the middle of the eighteenth century, but on the whole the development away from Latin was very slow and far from linear. There are still many important works first published in Latin throughout the eighteenth and the beginning of the nineteenth century, as the following sample shows. ${ }^{1}$

- Stochastics: Jacob Bernoulli, Ars coniectandi (Basileae, 1713).

- Botany: Samuel Gottlieb Gmelin, Flora sibirica sive historia plantarum Sibiriae, 4 vols (Petropolis, 1747-1769).

- Number $e$ and analysis: Leonhard Euler, Mechanica (Petropolis, 1736) and Introductio in analysin infinitorum (Lausannae, 1748).

- Botany: Carl Linnaeus, Systema naturae (Lugduni Batavorum, 1735).

- Medicine: Albrecht von Haller, Elementa physiologiae corporis humani, 8 vols (Lausannae, 1757-1766).

- Physics: Rogerius Boscovicius, Theoria philosophiae naturalis (Venetiis, 1758).

- History of Iceland: Finnur Jónsson, Historia ecclesiastica Islandiae (Hafniae, 1772-1778).

- Homeric studies: Friedrich August Wolf, Prolegomena ad Homerum (Halis Saxonum, 1795).

- Algebra: Carl Friedrich Gauß, Disquisitiones arithmeticae (Leipzig, 1801).

- Magnetism: Hans Christian Ørsted, Experimenta circa effectum conflictus electrici in acum magneticam (Copenhagen, 1820).

- Comparative linguistics: Franz Bopp, Glossarium sanscritum (Berlin, 1830).

1 Ogilvie (2015: 266) similarly stresses the importance of Latin at the universities up to 1800.

Ә Open Access. ( 2021 Philipp Roelli, published by De Gruyter. (C)BY This work is licensed under the Creative Commons Attribution 4.0 International License.

https://doi.org/10.1515/9783110745832-016 
- Mycology: Elias Fries, Systema mycologicum, 4 vols (Greifswald, 1821-1832).

- Oriental studies: Georg Wilhelm Freytag, Lexicon Arabico-Latinum, 4 vols (Halle an der Saale, 1830-1837).

- Mycology: Giacomo Bresadola, Iconographia mycologica, 29 vols (Milan, 19291933). ${ }^{2}$

The list shows, that, geographically, the last bastion of scientific Latin was mostly among scholars in Germanic and eastern parts of Europe: Gmelin and Euler worked in the Russian Empire; ${ }^{3}$ Boscovich stemmed from the Republic of Ragusa and was a Jesuit. ${ }^{4}$ In Hungary there were even some Latin newspapers for a short time, for instance Mercurius veridicus ex Hungaria (Levoča, 1705-1710), Nova posoniensia (Bratislava, 1721-1722), or the Ephemerides budenses (Budapest, 17901793). As the list suggests, in these regions important publications first published in Latin continued all through the nineteenth century. For instance, the mycologist Fries continued to publish in Latin into old age (Hymenomycetes europaei, Uppsala, 1874). In Germany this trend is exemplified most famously by Carl Friedrich Gauß, who even kept his own private diary in Latin (Klein 1903). Even the later twentieth century saw some natural-scientific Latin publications, although they must certainly be seen as curiosa, for instance Fenske, Extensio gradus, a mathematical paper on Fredholm operators written in 1979. From the nineteenth century onward, scientific Latin is more and more confined to a shrinking number of niches, some of which are now considered.

\section{(i) Titles and ornamental Latin}

\$2 Interestingly, books written in the vernacular often continued to use Latin titles from early on. Huser's edition (1603) of the works of Theophrastus Paracelsus (1493-1541) $)^{5}$ is called Opera, and uses headings such as Huserus benevolo lectori s[alutem], Volumen medicinae Paramirum Theophrasti de medica industria, Libellus prologorum primus, although the text is otherwise entirely written in German -

2 See Kustatscher \& Korenjak (2012: 1153-1154). The work is online at http://www2.muse.it/ bresadola/iconographia.asp?pt=IV.

3 Both stemmed from German-speaking areas. But native Russian eighteenth-century scientists, such as Michael Lomonosov, besides writing in Russian (which was becoming an important language then) also wrote at least some publications in Latin.

4 He was introduced above (chap. 13 \$4). More on the Jesuits as a last bastion of scientific Latin in $\S 7$ below.

5 Online at http://www.e-rara.ch/zut/content/titleinfo/3505565. 
a German of a rather macaronic ${ }^{6}$ character which uses Latin words and phrases all the time, but nonetheless German. It will be remembered (chap. 14 §2) that Paracelsus held his inauguration lecture in Basle in German, apparently to stress the novelty of his approach. Latin titles remained en vogue even after the time Latin ceased to be the usual medium of scientific communication. A few examples (the list could easily be extended):

- Ludwig Wittgenstein, Tractatus logico-philosophicus (London, 1921), in German and English.

- Johan Huizinga, Homo ludens (Haarlem, 1938), in Dutch (subtitle: Proeve eener bepaling van het spel-element der cultuur).

- Victor Klemperer, LTI [Lingua Tertii Imperii] (Berlin Ost, 1947), a book on Nazi language, in German (subtitle: Notizbuch eines Philologen).

- René Derolez, Runica manuscripta (Bruges, 1954), in English (subtitle: The English Tradition).

- Max Frisch, Homo faber (Berlin, 1957), a novel in German (subtitle: Ein Bericht).

- Walter Burkert, Homo necans (Berlin, 1972), in German (subtitle: Interpretationen altgriechischer Opferriten und Mythen).

- George Steiner, Errata (London, 1997), an autobiography in English (subtitle: An Examined Life).

- Thomas Leinkauf, Mundus combinatus (Berlin, 2009), in German (subtitle: Studien zur Struktur der barocken Universalwissenschaft am Beispiel Athanasius Kirchers SJ).

- Christian Jaser, Ecclesia maledicens (Tübingen, 2013), in German (subtitle: Rituelle und zeremonielle Exkommunikationsformen im Mittelalter).

- Johannes Fried, Dies irae (Munich, 2016), in German (subtitle: Eine Geschichte des Weltuntergangs). ${ }^{7}$

In general, such Latin titles seem especially common among authors who write in Germanic languages, among whom Latin, apparently, still enjoys high prestige. Nearly always, there is a subtitle in the book's actual language. The same applies to titles of book sections: in Schmitt's Anselm edition (1938) the first part is called Ratio editionis, despite being written entirely in German.

\footnotetext{
6 The term derives from the Opus macaronicum (1517) by Theophilus Folengus (1491-1544), online at https://archive.org/details/opusmacaronicumn00foleuoft. For this kind of language and writing, see Berschin (1972).

7 The list does not include Festschriften in philological fields, which bear Latin names very frequently.
} 
There would seem to be two reasons for doing this: on the one hand making use of Latin's prestige to make a work look cultivated, on the other hand the fact that certain titles, headings, and concepts are very familiar in Latin, especially in cases such as that of Schmitt. ${ }^{8}$ Besides, it can be observed in the twenty-first century - a time in which only very few scientists, and even scholars in the human sciences, have more than a basic smattering of Latin - that something we could call ornamental Latin springs into life. Above (chap. 9 §6), we saw how Berschin aptly coined the term ornamentales Griechisch for the Middle Ages. What is happening today is similar: the motivations for using Latin are providing a semblance of erudition but also a wish to embellish one's writing with the odd Latin term. Of course, the Latin is not always used in a way that makes sense in Latin (as was the case with Greek in the Latin Middle Ages). On the Internet and even in book publications, such pseudo-Latin abounds in certain circles these days. A recent example is David H. Cropley's Homo Problematis Solvendis - Problem-Solving Man: A History of Human Creativity, published by no less than the renowned Springer publishing house in 2019. The author teaches at the University of South Australia. His syntactically nonsensical Latin reminds one of Monty Python's famous Romanes eunt domus ('People called Romanes, they go the house'), in this case something like 'a man for those to solve of a problem'. Due to lack of knowledge of Latin among writers and readers alike, it matters little whether such 'Latin' is really Latin or not.

In fact, an ancient language that is no longer actively used among the intelligentia becomes rather unsuitable for expressing very modern thoughts that a Roman or a mediaeval scholastic would only have grasped after lengthy explanation. Thus, what authors such as Voltaire (chap. $14 \$ 5$ above) claimed, has become a self-fulfilling prophecy: the less the intelligentia cultivate Latin, the less Latin can keep pace with recent intellectual developments.

\section{(ii) Crypto-Latin}

\$3 Another niche for Latin was the concealment of indecent content. We propose the term 'crypto-Latin', from крú $\tau \tau \omega$ ('keep covered, esp. for purposes of concealment'), for this function. ${ }^{9}$ Authors using crypto-Latin obviously believed Latinate

8 Schmitt was able to write scholarly Latin. In Anselm's Opera, p. *1, it becomes clear that the introductory part was planned to be written in Latin in 1938 but the publisher then decided that the edition did not need an introduction. In the second printing, in 1962, in different times, Schmitt finally wrote it in German.

9 Strictly speaking, this term would rather imply that Latin was hidden (consider a crypto-Catholic, who hides his confession), but the prefix 'crypto-' does also have a similar use in some cases, such as 'cryptography', where writing is not hidden but is used to hide the content. 
people were mentally stable enough not to be put at risk by reading about indecencies, whereas simple - not Latinate - people might be tempted to imitate these indecencies or perversions. But there were also other, though related, reasons to hide behind Latin, such as in the early example of Nicolas Edme Restif de la Bretonne's autobiography Monsieur Nicolas, ou Le cœur humain dévoilé, published in 16 fascicles between 1794 and 1797. The most censure-worthy erotic details in this French book are written in Latin, for instance:

Je devins concentré, taciturne, sauvage, furieux de luxure; mais l'unique objet de ma frénésie était Colette, adhuc virgo a nullo tacta viro. (Restif de la Bretonne 1883: 4:27)

Les vêpres des Cordeliers ne duraient que trois quarts d'heure. Il fallait prévenir le retour $\mathrm{du}$ monde, et cependant Madelon bis terna venere fuit locupletata, dans ce court intervalle! ... Je ne pouvais la quitter. (4:145-146)

'I became concentrated, taciturn, wild, furious with lust; but the only object of my frenzy was Colette, adhuc virgo a nullo tacta viro. ${ }^{10}$

Vespers at Les Cordeliers lasted only three-quarters of an hour. It was necessary to expect the return of the people, and yet Madelon bis terna venere fuit locupletata, in this short interval! ... I could not leave off of her.'

He often also quotes longer excerpts from his journal in Latin, also mostly containing sexual adventures (e.g. 4:224). This author is quite unusual in telling his readers why he uses Latin:

Pour exprimer ceci, j'emploierai une langue savante, que les hommes seront forcés de traduire décemment aux femmes. (1:52)

'To express this, I will use a learned language, which men will be forced to translate decently to women.'

Women should not be able to read the more intimate sexual details. A more typical later, academic example of crypto-Latin is Krafft-Ebing's Psychopathia sexualis, published in $1886 .{ }^{11}$ Although the book was written in German, reports about some of his patients' behaviour that were seen as especially pathological are written in Latin; the author switches languages in the midst of a description without any comment. An example (von Krafft-Ebing 1886: 245):

Pat. war schwächlich als Kind, nervös, litt an nächtlichem Aufschrecken gleich seinem Vater, war aber von schweren Krankheiten nie heimgesucht bis auf Coxitis, seit welcher Pat. etwas hinkt. Sehr früh erwachten sexuale Dränge. Mit 8 Jahren, ohne alle Verführung, begann er zu masturbiren. Vom 14. Jahre ab ejaculirte er Sperma. Geistig war er gut veranlagt, inter-

10 In keeping with the authors' apparent wish, I refrain from translating these Latin passages.

11 Interestingly, a Russian scholar, Heinrich Kaan, had written a similar work with the same Latin title in 1844, but then still fully in Latin. 
essirte sich auch für Kunst und Literatur. Er war von jeher muskelschwach und hatte nie Neigung zu Knabenspielen und auch später nicht zu männlicher Beschäftigung. Er hatte ein gewisses Interesse für weibliche Toiletten, Putz und weibliche Beschäftigung. Schon von der Pubertät an bemerkte Pat. eine ihm unerklärliche Neigung für männliche Personen. Besonders sympathisch waren ihm junge Burschen aus den untersten Volksklassen. Ganz besonders zogen ihn Cavalleristen an. Impetu libidinoso saepe affectus est ad tales homines aversos se premere. Quodsi in turba populi, si occasio fuerit bene successit, voluptate erat perfusus; ab vigesimo secundo anno interdum talis occasionibus semen eiaculavit. Ab hoc tempore idem factum est si quis, qui ipsi placuit, manum ad femora posuerat. Ab hinc metuit ne viris manum adferret. Maxime periculosos sibi homines plebeios fuscis et adstrictis bracis indutos esse putat. Summum gaudium ei esset si viros tales amplecti et ad se trahere sibi concessum esset; sed patriae mores hoc fieri vetant. Paederastia ei displacet: magnam voluptatem genitalium virorum adspectus ei affert. Virorum occurrentium genitalia adspici semper coactus est. Im Theater, Circus u. s. w. interessiren ihn nur männliche Darsteller. Eine Neigung zu Damen will Pat. nie bemerkt haben. Er geht ihnen nicht aus dem Wege, tanzt sogar gelegentlich mit ihnen, aber er verspürt dabei nie die geringste sinnliche Regung.

'Patient was weak as a child, nervous, suffered from night terrors like his father had, but he was never afflicted by serious illnesses except for coxitis, since which patient has been limping a little. Very early sexual urges awakened. At the age of eight, without any seduction, he started to masturbate. From the age of fourteen he ejaculated sperm. Mentally he was well disposed, he was also interested in art and literature. He had always been weak-muscled and never had a tendency to play boys' games, or to engage in manly occupations later. He had a certain interest in female clothing, make-up, and female occupations. Already from puberty on, Patient noticed an inclination toward male persons which was inexplicable to himself. He was particularly fond of young boys from the lowest social classes. Most particularly, he was attracted to cavalrymen. Impetu libidinoso saepe affectus est ad tales homines aversos se premere. Quodsi in turba populi, si occasio fuerit bene successit, voluptate erat perfusus; ab vigesimo secundo anno interdum talis occasionibus semen eiaculavit. Ab hoc tempore idem factum est si quis, qui ipsi placuit, manum ad femora posuerat. Ab hinc metuit ne viris manum adferret. Maxime periculosos sibi homines plebeios fuscis et adstrictis bracis indutos esse putat. Summum gaudium ei esset si viros tales amplecti et ad se trahere sibi concessum esset; sed patriae mores hoc fieri vetant. Paederastia ei displacet: magnam voluptatem genitalium virorum adspectus ei affert. Virorum occurrentium genitalia adspici semper coactus est. In the theatre, circus, etc., only male performers interest him. Patient claims to have never noticed an inclination toward ladies. He does not avoid them, even dances with them occasionally, but he never feels the slightest sensual impulse.'

For the same reasons, sometimes in translations of 'explicit' Greek texts, passages were translated into Latin within a translation into a vernacular. Some such examples have been collected by Stray: ${ }^{12}$ for instance, the 1917 Loeb edition of the Alexandrian novel-writer Achilles Tatius, De Clitophontis et Leucippes amori-

12 Lawton (2012: 189). The Achilles Tatius passage is II.37-38, ed. Gaselee, pp. 129-133. 
bus, translates the final one and a half chapters of book II, which compare the experience of sex with boys and with women, into Latin although the text is otherwise translated into English. The translator does not comment on his change of language in the middle of a chapter, but the idea behind it is clearly the one proposed at the beginning of this section: uneducated people might be tempted to try out such things. It would be interesting to study this phenomenon in more depth. It can be seen as a special kind of Fachwerkstil (described in chap. $16 \$ 4$ below).

Interestingly enough, some crypto-Latin is still in use today, although not so much for indecent matters, which now no longer tend to be seen as problematic. For instance, in Switzerland pharmaceutical companies are not legally compelled to provide a full list of the ingredients of their medication, so they often list the major substances in the pill and add: excipiens pro compresso (sometimes adding obducto). The phrase literally means 'excepting [substances] for the completed pill' and is used as a means of concealing further, 'minor' substances in it, for various reasons. Thus, here Latin is also used to conceal information. ${ }^{13}$ The ingredients that are mentioned are still also listed in a 'Latin' form, such as Minocyclinum ut Minocyclini hydrochloridum. But there is no reason to see crypto-Latin here, as the names of the chemicals are the usual international ones with an -um at the end. The reader of such pharmaceutical 'literature' only needs to know that Latin genitives of neuter nouns in -um end in - $i$ and that $u t$ means 'as, in the form of'. This seems more to be a survival of pharmacists' Latin. The following niches for Latin were more substantial.

\section{(iii) University dissertations}

\$4 Doctoral dissertations were an important niche. At least in the human sciences, it was not unusual for dissertations to be written in Latin even in the middle of the twentieth century. ${ }^{14}$ In the nineteenth century, it was rather unusual to write any dissertation in any other language in Europe. As an example, the University of Greifswald allowed German as well as Latin for medical dissertations only in 1867, for juristic ones in 1876, and for all fields in the Geisteswissenschaften in $1879 .{ }^{15}$ University teaching had already been done in the vernacular languages in many places for about a century by then. Greifswald is an interesting

13 A brief Internet search brings up blogs where (e.g. allergic) people discuss what these ominous words might mean, and then vent their (justified) anger about not being informed properly. 14 Marti (1998). For an overview of theses and dissertations in early modern times in general, see Marti (2001).

15 The numbers and the information that follows are from Alvermann (2018). 
case, as one can see here that there was not necessarily a linear development from Latin to the vernacular at universities. Already in 1739, Augustin von Balthasar wrote a German dissertation and in 1753 Hermann Ahlwardt tried to prove the fitness of German in Den vorzüglichen nutzen der Teutschen Sprache angestellten Akademischen Streithandlungen ('The Formidable Usefulness of Academic Disputations Held in German'). ${ }^{16}$ But as Greifswald then became part of the Swedish Empire, the use of Latin rose again in the late eighteenth century (as in Sweden generally). In 1794 the 'Greifswald consensus' reached the compromise that pure sciences had to use Latin, whereas applied sciences (artes) could use German or Latin, thus upholding a distinction that had come about centuries earlier. In comparison, the Habsburg lands already allowed German as a teaching language in 1784. Universities used Latin as the common spoken language at least until the middle of the eighteenth century almost everywhere. ${ }^{17}$

Cicero and Quintilian were often used as models for the language employed in dissertations, as their Latin was the kind drilled at the gymnasium. But academic Latin was certainly much more indebted to mediaeval and scholastic Latin than many of its more classicist users would have liked to admit. ${ }^{18}$ Swedish Latin dissertations are currently being studied in detail. ${ }^{19}$ Benner \& Tengström (1977) studied the language of ten Swedish learned texts (mostly dissertations) from the seventeenth century. Initial conclusions about the literary background, vocabulary (esp. 52-61), grammar, and style were reached. But it was still too early to move far beyond rather general results such as the following (106):

The learned Neo-Latin of the 17th century cannot be said to have been a 'dead' or petrified language, not even a dying one. It was subjected to certain changes, mostly concerning the vocabulary. It could be moulded to very different purposes and be adapted to various styles.

In the meantime, significant advances have been made. For instance, Sjökvist (2012: 38-57) provides a list of rare terms and neologisms in three Swedish musicology dissertations from the seventeenth century. He finds that most neologisms (94 of 111) are nouns, something that does not seem to be typical, as the data below in appendix 1 (context: chap. 18 §) shows. Among the often-quoted advantages of Latin are its elaboration and adaptation to many fields, its already existing specialised vocabulary, the general usus, and possibly sometimes also the fact that some technical knowledge should not reach simple people (see $§ 2$ above on crypto-Latin).

16 Online at http://mdz-nbn-resolving.de/urn:nbn:de:bvb:12-bsb10667132-4.

17 Dates when this changed for several European universities in Waquet (1998: 38-42).

18 Hörstedt (2018: 39) comes to the same conclusion.

19 e.g. Helander (2004); Gunnarsson (2011); Sjökvist (2012); Hörstedt (2018). 


\section{(iv) Botany}

\$5 Botany, like medicine, already had a highly specialised, vast vocabulary in the days of Carl Linnaeus (1707-1778), the father of modern botany, who still wrote in Latin. He invented the modern binomial biological nomenclature for species, formed of the Latin or Latinised genus name followed by a species name (such as Homo sapiens). Even today, most plant genera bear names that are one of the following. ${ }^{20}$

- (Latinised) Greek or Latin names from Antiquity (such as the genera Acacia, Aconitum; Allium, Apium, Brassica).

- Mediaeval Latin ones (Humulus, Maiorana, Primula).

- Oriental, often Arabic, ones, mostly for non-European plants (Camphora, Catha).

- More rarely, from the mediaeval European vernacular languages (Canella, Galega).

- Modern coinings from Greek and Latin elements (Aceriphyllum, Alternanthera).

- Modern coinings based on botanists' names (Maclura, Rudolfiella).

- Wucherformen such as Echinofossulocactus, Gymnanthocereus. ${ }^{21}$

Species names are usually originally adjectives characterising the species within the genus (often: vulgaris, sativus, medicinalis) or genitives (Magnolia sieboldii), but sometimes the two names are rather to be understood as a kind of apposition: Pistacia lentiscus = a pistacia that is called lentiscus. This system is maintained to this day, so discoverers of new species must at least be able to put the adjective into the correct gender or genitive form in Latin. Very rarely do we find names that would seem badly formed, like Solanum dulcamara, in which dulcamarus (a rare and late compound used e.g. once by Iustus Lipsius as dulcamaro sermone) ${ }^{22}$ should be neuter. Some name forms look erroneous but are not, thus Schinus molle, a tree from Peru which produces pepper-like fruit, where one would expect that schinus, being a feminine (from oxĩvos, 'mastic-tree'), should take mollis; but molle is a non-Latin noun used as an apposition here. ${ }^{23}$ Some botanical sources do indeed 'correct' to mollis. The same genus once contained an erroneous name: Antonio José Cavanilles (1745-1804) named a tree Amyris polygamus, which was

20 The list follows Genaust (1976: 12-18).

21 Groups from Genaust (1976). He was not able to trace the etymologies for some thirty genera.

22 In Sylloge epistolarum a viris illustribus scriptarum, vol. 1, ep. 264, found using Corpus Corporum. The word is documented in the Hungarian Mediaeval Latin dictionary by Harmatta et al.

23 Linnaeus, Species plantarum, pp. 388-389, took the name from Monardes, De simplicibus medicamentis, p. 48, who describes the tree and quotes its native American name as 'Molle'. 
placed into our genus in 1937 as (wrongly) Schinus polygamus, later corrected to Schinus polygama, as schinus is a feminine noun. ${ }^{24}$

This complicated and highly functional Latin-based system of nomenclature made a transition to the vernacular languages especially problematic. ${ }^{25}$ Indeed, these Latin names are still the only ones used in scientific contexts. Moreover, new plant species had to be described by their discoverer in a highly standardised Latin that owed much of its characteristics to Linnaeus, until 2014. Special manuals taught this kind of international language, such as Stearn (1966). Since 2015 these first descriptions may also be written in English (which, of course, means that they are now exclusively written in English). As an example, we can quote the Latin description of Wollemia nobilis, a famous living fossil discovered in Australia in 1994. Not only the species was new to science but also the genus. A short Latin description of the new genus is given, before further description in English: ${ }^{26}$

Agathi affinis, sed characteribus sequentibus differt: folia trimorpha, helicalis, decurrentia; strobili terminales, bracteae squamaeque perfecte connatae spiniferaeque; semina ala cincta. 'Similar to the genus Agathis, but it differs from it in the following respects: trimorphic, winding, hanging leaves; terminal cones; perfectly connate and spine-bearing lamellae and scales; the seeds are girded by a wing.'

The same procedure is repeated for the species:

\begin{abstract}
Arbor elata cortice nodosa spongiosaque; rami inferi foliis distichis, linearibus, obtusis, hyperstomaticis; rami superior foliis tetrastichis, oblongis, obtusis, amphistomaticis; strobuli masculi magni, 7-11 cm longi, 13-19 mm diametro.

'High tree with knotty and porous bark; the lower branches with two-rowed, linear, obtuse, hyperstomatic leaves, the upper ones with four-rowed, oblong, obtuse, amphistomatic leaves; the male cones are big, 7-11 cm long with a diameter of 13-19 mm.'
\end{abstract}

At the end, the sentence 'We thank [...] Peter Wilson for assistance with Latin diagnoses' reveals that a few Latin specialists occupied themselves with polishing or even translating these Latin 'diagnoses' up to 2015. Of course, even now, without hardly any more Latin diagnoses published, Latin still has its place in botany: the names of new species are still chosen following the Latin rules detailed above. As the list above shows, entire Latin monographs were still frequent all through the nineteenth century in this discipline.

24 http://www.ipni.org/ipni/idPlantNameSearch.do?id=1073576-2 .

25 Also pointed out by Korenjak (2016: 160).

26 From Jones, Hill \& Allen (1995). 


\section{(v) Philology, especially classical philology}

\$6 A field in which Latin had an obvious advantage was classical philology. Those studying it cannot avoid knowing Latin. Through the nineteenth century, Latin was used as a matter of course in many publications in this field. In 1892, Wilamowitz-Moellendorff predicted that the twentieth century would bring 'die Abschaffung des Griechischen und Beschränkung des Lateinischen auf einen elementaren Sprachunterricht' ('the abolition of Greek and the restriction of Latin to elementary language teaching') in school. ${ }^{27} \mathrm{He}$ continued to claim that despite the fact that the German people 'den Bruch mit der Geschichte und der Kultur endgültig vollzöge' ('would break with its history and culture for good'), classical philologists would continue to exist at universities, albeit more like semitologists or indologists, as specialists of faraway languages and cultures. WilamowitzMoellendorff was right. Thus, although Latin had stayed alive as an important written language far into the nineteenth century in classical philology, it diminished even in this rôle in the twentieth. Some of the most important contributions to the field were still written in Latin, for instance Karl Lachmann's In T. Lucretii Cari De rerum natura libros commentarius (Berlin, 1850). Heiberg in his Euclid edition from 1883 still translates the Greek texts into Latin, not one of the vernacular languages, since he believes (vol. 1, p. viii):

Nam quamquam videbam, Latinam interpretationem meam a nonnullis improbari, tamen hic quoque Latinam Francogallicae Germanaeve aut nulli praetuli; nam interpretationem mathematici flagitant, et Latina a pluribus legi potest.

'For although I foresaw that some would disapprove of my Latin translation, I yet prefer one in Latin to one in French, German, or none at all, for mathematicians demand a translation and Latin is read by most.'

For the very same reasons, many important grammars and dictionaries of oriental languages were still written in Latin in the nineteenth century, such as Carolus Paulus Caspari's Grammatica arabica in usum scholarum academicarum (Leipzig, 1848), ${ }^{28}$ or Georg Wilhelm Freytag's Lexicon arabico-latinum (Halle an der Saale, 1830-1837), which is still today often indispensable and sometimes superior to Lane's large standard Arabic-English dictionary. Even in 1920, Tkatsch still translated the Arabic version of Aristotle's Poetics from Arabic into Latin as a kind of 'neutral' language in which he hoped to be able to imitate the syntactic and lexi-

27 In a speech printed in Wilamowitz-Moellendorff (1901: 101). Quoted and discussed in Fuhrmann (2001: 217).

28 Online at http://reader.digitale-sammlungen.de/en/fs1/object/display/bsb10571520_00053. html. 
cal details of the Arabic in order to acquaint the non-Arabist scholar with them. ${ }^{29}$ Other orientalists strongly disagreed; the great Syriac scholar Baumstark called Latin a 'fragwürdiger Aufputz pseudociceronianischer Sprache' ('questionable finery of pseudo-Ciceronian language') in 1900. These emotional words clearly show that Latin was still one of several possible languages for orientalist scholarship, but Baumstark continues 'dass kaum irgendeine Sprache zur Übersetzung semitischer Texte und zur Behandlung semitistischer Gegenstände minder geeignet ist als die lateinische' ('that hardly any other language is less suitable for the translation of Semitic texts and the treatment of Semitic subjects than Latin'; 1900: x).

Semitists, indeed, stopped using Latin in the first half of the twentieth century. In contrast, Latin has been retained especially tenaciously as the language of prefaces to monolingual editions of texts in the classical languages. The matters to be discussed are rather monotonous, and it will be felt that readers who can read the Latin or Greek edited text will not be put off by a Latin introduction, and will certainly understand it, in contrast to any single one of the vernaculars. In the Bibliotheca scriptorum graecorum et romanorum teubneriana, and until recently in the Oxford Classical Texts, prefaces were universally written in Latin. The first exception for the latter series was the English preface by Lloyd-Jones and Wilson in their Sophocles edition (1990). Occasionally, even in the twentyfirst century scholarly research papers are written in Latin, for instance Briesemeister \& Schönberger, De litteris neolatinis (published in 2002). But as schools do not teach Latin composition any more, those able to write Latin are becoming fewer and fewer.

\section{(vi) Catholic theology, especially Jesuit school Latin}

\$7 Latin was largely used as the medium of communication within the Catholic Church before Vatican II (1962-1965), which famously abolished Latin Mass and in general strove to modernise the Church. Theological works were still often written in Latin in the twentieth century, as the list below will illustrate. The Roman Pontificia Università Gregoriana, a university originating from the Jesuit Collegium Romanum, taught theology in Latin until the late 1960s. Today the Vatican still offers parts of its homepage in Latin, ${ }^{30}$ mostly a collection of legal texts, encyclicals, letters, and so on. In contrast, the main page containing practical and pas-

29 Petitmengin (2012) ventured a foray into the uncharted waters of French translators who translated from Greek to Latin in the nineteenth century.

30 http://www.vatican.va/latin/latin_index.html . 
toral matters exists in several modern languages but not in Latin (as of 2018). From 1566 to 1989, the Church used the Catechismus romanus, from 1990 on the Catechismus catholicae ecclesiae; for both, the Latin version remains the authoritative one. Although not affiliated with the Church, Rome is today again home to a college where Latin (and Ancient Greek) are exclusively used in teaching: the Vivarium Novum. ${ }^{31}$ In 2007, Pope Benedict XVI opened a back door for the abolished Latin Mass with his encyclical Summorum pontificum. ${ }^{32}$ Since then, Latin Mass can quite regularly be heard again in some churches. Thus, Latin can still be said to be alive to some extent in the Catholic environment.

Since its formation in 1540 by Ignatius of Loyola, the Jesuit Order was especially dedicated to teaching and science. ${ }^{33}$ of course, back then teaching meant teaching in Latin. For political reasons, the order was suppressed in 1773-1814 (except in Prussia and the Russian Empire, which did not want to lose their Jesuit schools); afterwards, it had much less influence over a very different world, but it clung tenaciously to Latin. School textbooks used in Jesuit schools remained in Latin throughout the first half of the twentieth century. Strictly speaking, this may be more school Latin than scientific Latin, but the structure would be the same in scientific use. It may be useful to quote a paragraph of this largely forgotten kind of twentieth-century Latin. Carolus Boyer explains biological evolution in 1952 (Cursus philosophiae q. 4, a. 2, §1.IIA, vol. 2, p. 185):

Transformismus universalis est simul vel monisticus vel theisticus; monisticus quidem, si evolutionem aut casu et fortuna, aut vi quadam immanente integre explicat. Ita Darwin, qui transformismum specierum explicat praesertim per selectionem naturalem: scilicet, ex multis formis parum diversis quae generatione oriuntur, illae tantum permanent quae aptiores sunt ad pugnam pro vita ('struggle for life'); debiliores autem pereunt; magnum influxum quoque exercet selectio sexualis, quae resultat ex pugnis inter mares et ex inclinationibus feminarum. Sic continuis et parvis mutationibus paulatim magnae differentiae acquiruntur, dum formae intermediae pereunt. Cui systemati Weissmann addidit selectionem intragerminalem, quae nempe fiat inter determinantia, seu elementa chromosomatum, in cellulis generationis.

'Universal transformism (evolution theory) is at the same time either monistic or theistic. Monistic if it explains evolution fully either by accident or chance, or by another immanent force. This is done by Darwin, who explains the transformations of species particularly by natural selection, i.e. out of many slightly different forms that are generated, only those remain that are better adapted to the struggle for life. The weaker ones die. Another great influence is exercised by sexual selection resulting from fighting between males and from the

31 In Frascati on the outskirts of Rome, https://vivariumnovum.net; the name alludes to Cassiodorus' Vivarium.

32 Online at http://w2.vatican.va/content/benedict-xvi/la/motu_proprio/documents/hf_benxvi_motu-proprio_20070707_summorum-pontificum.html.

33 See Feingold (2003a). 
predilections of females. Thus, large differences are by and by acquired through continuous and small changes, whereas the middle forms disappear. To this system [August] Weismann added intra-germinal selection, which happens among genes or chromosomes in germ cells.'

Later on, more theistic alternatives are also discussed. This is a language that is easily understandable but expresses its modern scientific content effortlessly. It could very well have been used as an international scientific auxiliary. It can be called pragmatic Latin..$^{34}$ For a variety of reasons - politics, school curricula de-emphasising Latin, dislike outside the Catholic Church of all things Jesuit, last and not least Vatican II - this did not happen, and this kind of Latin has been so utterly forgotten in the past half-century that it looks like a lost continent to us today. In order to give an impression of its size and importance, a chronological list of some such twentieth-century Jesuit textbooks dealing with scientific topics (sensu lato) is presented here; many of them were intended for school use but some also for higher, university studies. ${ }^{35}$

- Stanislaus De Backer, Institutiones metaphysicae specialis, 4 vols (Paris: Delhomme et Briguet (vols 1-2); Beauchesne (vols 3-4), 1899-1904). Vol. 1, Cosmologia, cui adnexa est disputatio de accidente. Vol. 2, De vita organica. Vol. 3, De vita rationali. Vol. 4, Theologia naturalis.

- René Jeannière, Criteriologia vel critica cognitionis certae (Paris: Beauchesne, 1912).

- Aurelius Palmieri, Theologia dogmatica orthodoxa (ecclesiae Graeco-Russicae) ad lumen Catholicae doctrinae examinata et discussa (Florence: Libr. Editr. Fiorentina, 1911-1913).

- Victor Cathrein, Philosophia moralis, 10th ed. (Freiburg im Breisgau: Herder, 1915).

- Joseph Donat, Ethica, 2 vols (Innsbruck: Rauch, 1921).

- Friedrich August Klimke, Institutiones historiae philosophiae, 2 vols (Rome: Univ. Gregoriana, 1923).

- A. R. P. Eduardus Hugon, Cursus philosophiae thomisticae: Philosophiae naturalis, vol. 2, Cosmologia, biologia, psychologia (Paris: sumptibus P. Lethielleux, 1927).

- Martin Jugie, Theologia dogmatica christianorum orientalium ab ecclesia catholica dissidentium, 5 vols (Paris: Letouzey et Ané, 1926-1935).

34 As does Leonhardt (2013: 243), contrasting it with humanist Latin.

35 I mention the editions I happened to have access to. Many of these books are hard to find even in large university libraries today. Protestant Zurich (where I am writing) is especially badly stocked with this kind of literature. 
- Joseph Fröbes, Psychologia speculativa (Freiburg im Breisgau: Herder, 1927). Also as a cursus brevior (1933).

- Louis de Raeymaeker, Introductio generalis ad philosophiam Thomisticam, 2 vols (Leuven: Nova et vetera, 1931).

- Louis de Raeymaeker, Metaphysica generalis, 2 vols (Leuven: apud E. Warny, 1935).

- Carolus Boyer, Cursus philosophiae, 2 vols (Paris: Desclée de Brouwer, 1952).

- Philosophiae scholasticae summa, 3 vols (Madrid: Biblioteca de Autores Cristianos, 1952-1957). Vol. 1, Introductio in philosophiam, Logica, Critica, Metaphysica generalis, by Leovigildo Salcedo \& Jesús Iturrioz. Vol. 2, Cosmologia, Psychologia speculativa, by José Hellín \& Ferdinando M. Palmes. Vol. 3, Theodicea, Ethica, by José Hellín \& Ireneo González.

- Paul Siwek, Psychologia metaphysica: Institutiones philosophiae aristotelicoscholasticae, 5th ed. (Rome: Pont. Univ. Gregoriana, 1956).

- Institutiones philosophiae scholasticae, 6 vols (Freiburg im Breisgau: Herder, 1925-1964). Vol. 1, Logica cui praemittitur introductio in philosophiam, ed. J. de Vries. Vol. 2, Critica, ed. J. de Vries. Vol. 3, Ontologia, ed. J. B. Lots. Vol. 4, Philosophia naturalis in usum scholarum, ed. Carl Frank. Vol. 5, Psychologia metaphysica, ed. Alexander Willwoll. Vol. 6, Theologia naturalis, ed. Walter Brugger.

This list could easily be extended, but it will be sufficient to show the vitality of the genre up to Vatican II, which brought this lively tradition to an abrupt end, together with many other pieces of centuries-old culture. ${ }^{36}$ Among the authors, we find Poles, Spaniards, Italians, Frenchmen, Austrians, and Germans: ${ }^{37}$ there was a truly international auxiliary language for the sciences and education.

The structure of the argumentation in most of these books was very similar to the traditional scholastic approach: there are quaestiones, articuli, scholia, respondeo, argumenta. The authors do not mind using neologisms in their vocabulary, often shaped according to vernacular usage if the words are correctly formed from Latin and Greek constituents: ${ }^{38}$ palaeontologia, fossile, anthropomorphicus, evolutionismus, transformismus, creationismus vel fixismus, ${ }^{39}$ monophyleticus, idealista,

36 Internet searches reveal that even today, there is still a strong opposition to the new postVatican II Catholicism in some circles.

37 The English are missing because Catholicism was outlawed until the nineteenth century and the Catholic structures had by then all but disappeared.

38 Examples from Boyer, Cursus philosophiae; the text is searchable online at http://mlat.uzh. $\mathrm{ch} / ? \mathrm{c}=4 \& \mathrm{w}=$ BoyCar.CurPhil.

39 Which is, incidentally and in contrast to many Protestant sects still today, rightly rejected as unscientific by Boyer, Cursus philosophiae, Psychologia q. 4, a. 2, §1.IIC, vol. 2, pp. 186-187. 
elementa chromosomatum, conatus vitalis (élan vital), determinantia (i.e. genes), scientista, positivista, liceitas - words that would be seen as the pinnacle of barbarism by Ciceronians, for whom this kind of Latin would be at least halfway toward Giuseppe Peano's Latino sine flexione (chap. 14 \$10). But such criticism seems ill-founded and based on a misunderstanding of the nature and function of language: Latin as a living language of erudition would have to behave exactly as it does in these Jesuit manuals if it was to function well. That it was discontinued was purely a political decision. The next chapter presents selected aspects of the change from Latin to vernacular in science and learning. 